Çukurova Üniversitesi Mühendislik Mimarlık Fakültesi Dergisi, 33(1), ss. 67-82, Mart 2018

Çukurova University Journal of the Faculty of Engineering and Architecture, 33(1), pp. 67-82, March 2018

\title{
Güneş Hücrelerinin Performansına Baranın Etkisinin İncelenmesi
}

\author{
Furat EKINC $\dot{I}^{* 1}$ \\ ${ }^{1}$ Adana Bilim ve Teknoloji Üniversitesi, Enerji Sistemleri Mühendisliği Bölümü, Adana
}

Geliş tarihi: 20.12.2017～Kabul tarihi: 14.03.2018

Öz

Güneş ışınımın fotovoltaik paneldeki güneş hücrelerinde elektrik enerjisine dönüştürme işlemi, en bilinen ve kullanılan yenilenebilir enerjiden elektrik üretim yöntemidir. Bir fotovoltaik sistemin kalbi güneş modülüdür. Birçok güneș hücresi lehimle ile bir araya getirilerek bir fotovoltaik modülü oluşturulur. Modülde elektrik üretimi, çok katmanlı yarı iletken malzemeden oluşan güneş hücreleri tarafindan üretilir. Güneş ışınımları hücrelerin üzerine geldiği zaman bu katmanlar arasındaki elektromotor kuvveti oluşturarak elektrik akışını meydana getirir. Güneş 1şınımı şiddeti ne kadar yüksek olursa elektrik akışı da o kadar yüksek olur. Bu çalışmada, farklı ışınım değerlerinde güneş hücresindeki baraların sayısının elektrik üretim performansına etkisi MATLAB programı kullanılarak modellenmiş ve deneysel sonuçlarla ayrıntılı bir şekilde etkisi araştırılmışıı. Bu çalışma ile güneş hücrelerindeki baranın elektrik üretimine etkisi açık bir şekilde ortaya koyularak bu alanda çalışan araştırmacılara yön verilmesi amaçlanmıştır. Ayrıca, güneş enerjisi uygulamalarında çok baralı güneş hücrelerine geçilerek elektrik üretim performansının artırılması yanı sıra güneş hücrelerinde zamanla oluşan olumsuzlukların da azaltılması sağlanacaktır. Benzetim sonuçları ile deneysel çalışma kıyaslandığında; voltaj değerlerinde çok yakın sonuçlar elde edilirken akım değerlerinde biraz farklılık görülmektedir. Bu farklılık, seçilen direnç değerinden kaynaklanmaktadır.

Anahtar Kelimeler: Güneş hücresi, Elektrik üretimi, Verimlilik, Bara(BB), Yenilenebilir enerji

\section{Investigation of Busbar Effect on Performance of Solar Cells}

\begin{abstract}
The transformation of solar radiation into electricity in the solar cells of the photovoltaic panel is the most commonly used and renewable energy production method. A photovoltaic system is the heart of solar module. Many solar cells are combined with solder to form a photovoltaic module. Electricity generation in the module is produced by solar cells consisting of multi-layered semiconducting material. When the sun's rays reach their cells, the electromotive force between these layers occurs and the electric current flows. The higher the intensity of solar radiation, the higher the electric current flow. In this study, the
\end{abstract}

*Sorumlu yazar (Corresponding author):Firat EKİNCi,,fekinci@adanabtu.edu.tr 
effect of the number of busbar in the solar cell on the electricity production performance of different solar radiation values was modeled using MATLAB program and the effect was investigated in detail with experimental results. With this study, it is aimed to clarify the effect of the busbar of solar cells on electricity generation and to direct the researchers working in this area. In addition, in solar energy applications, it will be possible to increase the electricity production performance by passing to very coherent solar cells, as well as to reduce the negativity that occurs in the solar cells over time. Both simulation and experimental results are compared; it is showed that the voltage values are nearly close but the current values are approximately different. This difference is related to the resistance characteristics.

Keywords: Solar Cell, Electric production, Efficiency, Busbar (BB), Renewable energy

\section{GİRIŞ}

Güneş hücreleri, N-tipi ve P tipi çok katmanlı yarı iletken malzemelerden meydana gelmiştir. Bu yarı iletkenler sayesinde güneş 1şınımı elektrik enerjisine dönüştürülür. Güneş 1şınımı yarı iletken malzemeler tarafından emildiğinde katmanlardaki elektronları atomlarından koparır ve elektronların akışına izin vererek elektriğin üretilmesini sağlar. Işığı (fotonlar) elektrik (voltaj) haline dönüştürme işlemi fotovoltaik (PV) etki olarak adlandırılır. Günümüzde güneş panelleri [1-6], görünür 1 şık tayfının çoğunu, ultraviyole ve kızılötesi 1 şık tayfının yaklaşık yarısını kullanılabilir elektrik enerjisine dönüştürür.

Güneş panellerinde hücreleri birbirine bağlamak için bara (BusBar-BB) denilen elektrik ileten ince bir bakır veya alüminyum şerit kullanılır. Lehimlenerek güneş hücrelerini birbirine bağlayan baralar (BB); güneş hücrelerini birleştirir ve hücrelerinden toplanan doğru akımı alternatif akıma dönüştüren güneş evirgeçine (invertör) iletir. Güneş panellerinde maksimum akım miktarına bara boyutu etki eder. Barların boyutları değişken olup, $10 \mathrm{~mm}^{2}$ 'lik alan kadar küçük olabilir. Güneş panellerinde, baralar (BB) tipik olarak yassı şeritlerdir ve kesit alanı oranına bağlı olarak ısının daha verimli bir şekilde dağılmasını sağlar [1-3].

İlave baralar hücreler arasında daha düşük direnç oluşturur. Ohms Yasası'na göre direnç (ohm, R veya $\Omega$ ) aşağı inerken, akım (amper) yükselir ve aynı voltaj için akım arttığında güç (volt kere amperdir) yükselir. İlave baraların güneş hücrelerinin birleştirilmesinde kullanılması güneş panellerinin yaklaşık \%2 daha verimli olmasını sağlar. Bu, aynı boyuttaki güneş panelinde daha az baralı birleştirilmiş güneş hücrelerine göre $\% 2$ daha fazla güç üretebilecekleri anlamına gelir [1-3]. Tek baralı (BB) bir güneş paneli Şekil 1'de gösterilmiştir. Şekil 2'de ise farklı baralı güneş hücreleri gösterilmiştir.

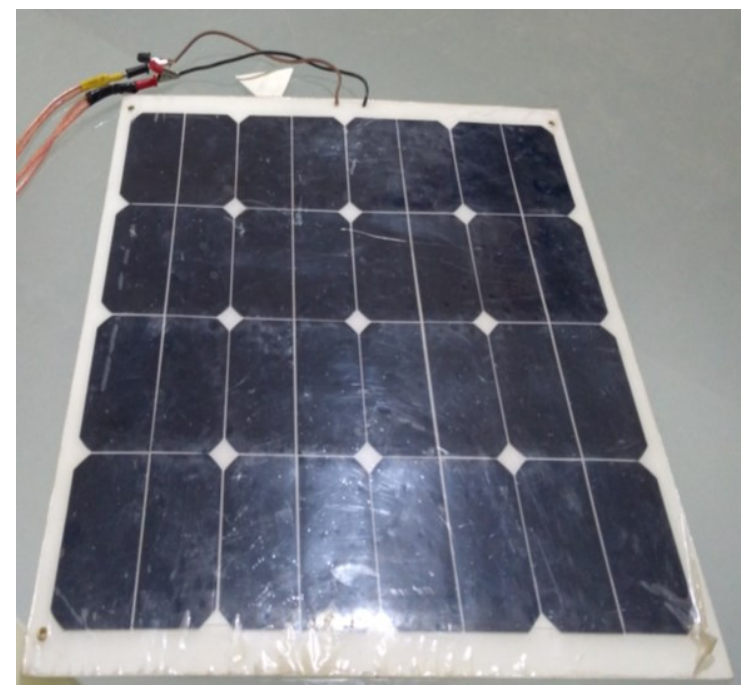

Şekil 1. Tek baralı (BB) güneş paneli

$\mathrm{Bu}$ çalışmada, baraların sayısı arttıkça güneş hücresinin elektrik üretim performansına etkisi farklı 1şınım şiddetinde ayrıntılı bir şekilde incelenmiştir. Bu çalışmada 2, 3 ve 4 baralı güneş hücreleri ile esnek güneş hücrelerinden oluşmuş modüllerin elektrik üretim performansı teorik değerlendirilmesi için MATLAB programı ile benzetim çalışmaları yapılmıștır. Teorik sonuçlar, farklı 1şınım şiddeti değerlerinde test edilen modüller için deneysel sonuçları ile karşılaştırılmıştır. 

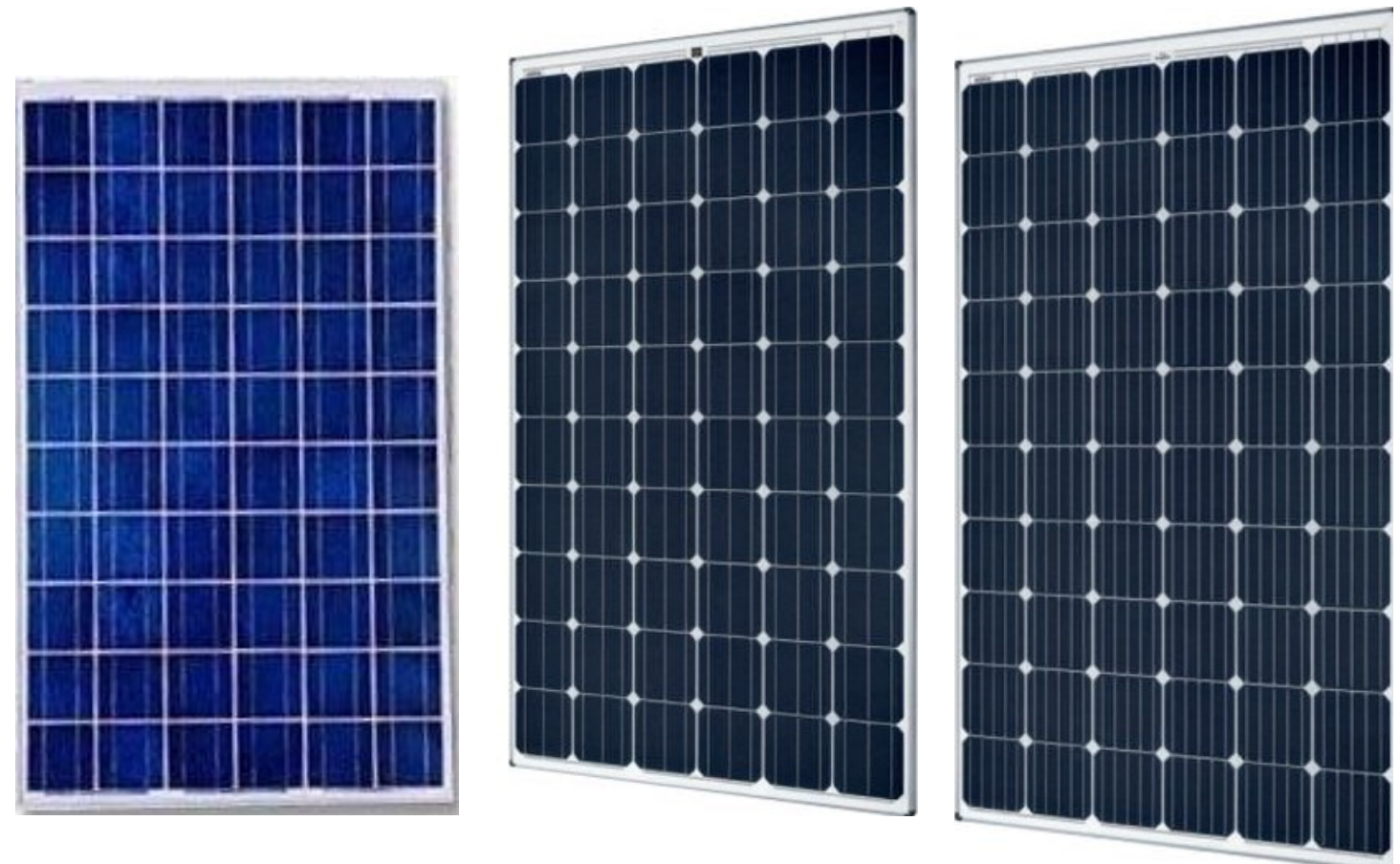

Şekil 2. Farklı baralı (BB) güneş hücreleri

\section{GÜNEŞ HÜCRELERININ YAPISI VE ÇALIŞMA PRENSİBİ}

Bir güneş hücresi, Şekil 3'de gösterildiği gibi p-n birleşim yeri 1şı̆ga maruz kalan anti-paralel yarı iletken diyotlu bir akım kaynağıdır. Bir güneş hücresi ayrıca, metal tabanının p-tipi yarı iletken ile temas direnci $p$, ve cisimlerinin direnci $n$, tabakanın üst metal kısmina temas direnci nedeniyle seri direnci $\mathrm{R}_{\mathrm{s}}$ ile gösterilir. Üretilen bazı akımlar, PV hücresinin imalatı nedeniyle sızıntı akımına da neden olur ve bu da şönt direncini $R_{s h}$ oluşturur. $R_{s h}$ değeri genellikle yüksekken $\mathrm{R}_{\mathrm{s}}$ değeri düşüktür. İdeal bir güneş pili seri ve şönt direnci sunmaz [4-6]. Tek bir ideal güneş hücresinin akımı I ile voltajı $\mathrm{V}$ arasındaki ilişkiyi yöneten temel bağlantı Eşitlik 1'de verilmektedir.

$I=I_{p v}-I_{o}\left[e^{\left(\frac{q\left(V+I R_{s}\right)}{\alpha K T}\right)}-1\right]-\frac{V+I R_{s}}{R_{s h}}$

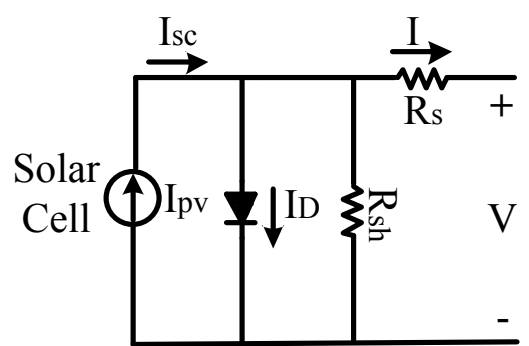

Şekil 3. Bir güneş hücresi modeli

Burada, $I_{p v}$, yük 1șığı tarafindan üretilen akımdır, $I_{d}$, diyot akımı, $I_{o}$, diyotun ters doygunluğu ya da sızıntı akımı, $I_{r}$, paralel direnç yoluyla akım, q, elektron şarjıdır $\left(1,6 \times 10^{-19}{ }^{\circ} \mathrm{C}\right), \mathrm{K}$ Boltzmann sabiti $\left(1,38 \times 10^{-23} \mathrm{~J} / \mathrm{K}\right), \mathrm{T}, \mathrm{p}_{\mathrm{n}}$ kavşağının Kelvin'indeki sıcaklığg ve $\alpha$ ise 1,0 ile 1,5 arasında değişen düzeltme faktördür. Eşitlik 1, temel bir Kirchhoff'un yasasını gösterir.

Diyot doyum akımı I ve sıcaklığa olan bağımlılığı Eşitlik 2 ile ifade edilebilir: 


$$
I_{o}=I_{o, n}\left(\frac{T_{n}}{T}\right)^{3} e^{\left[\frac{q E_{g}}{\alpha K}\left(\frac{1}{T_{n}}-\frac{1}{T}\right)\right]}
$$

Burada, $\mathrm{E}_{\mathrm{g}}$ yarı iletkenin bant boşluğu enerjisidir, $\mathrm{T}_{\mathrm{n}}$ nominal sıcaklıktır (298 Kelvin) ve $\mathrm{I}_{\mathrm{o}}$, n Eşitlik 3 ile verilen nominal doyma akımıdır. Buradaki n, nominal koşulları belirtir.

$$
I_{o, n}=\frac{I_{s c}}{e^{\left(\frac{V_{o c}}{\alpha V_{t}}\right)}-1}
$$

Burada $\mathrm{V}_{\mathrm{oc}} \mathrm{PV}$ modülünün açık devre voltajı ve $\mathrm{I}_{\mathrm{sc}}$ modülün kısa devre akımı ve $\mathrm{V}_{\mathrm{t}}$ termal voltaj olarak tanımlanır.

$\mathrm{N}_{\mathrm{s}}$ sembolü, bir dizideki seri hücrelerin sayısıdır. Modülün 1şıktan üretilen akımı güneş radyasyonuna doğrusal olarak bağlıdır ve ayrıca Eşitlik 4'e göre sıcaklıktan etkilenir.

$$
I_{p v}=\left[I_{s c}+K_{i}\left(T-T_{n}\right)\right] \frac{G}{G_{n}}
$$

$\mathrm{K}_{\mathrm{i}}$, kısa devre akım/sıcaklık katsayısını, G, W/m² cinsinden güneş 1 şı̆̆ 1 ve $G_{n}, W / m^{2}$ cinsinden nominal güneş ışıııımı değeridir.

\section{LITERATÜR ÇALIŞMASI}

Literatür çalışmalarına bakıldığında ülkemizde yenilenebilir enerji kaynakları ile ilgili birçok çalışma bulunmasına rağmen güneş hücrelerinin performansı etki eden baralar ilgili herhangi bir çalışmaya rastlanmamıştır. $\mathrm{Bu}$ çalışmanın amaçlarından biri de ülkemizdeki araştırmacılara güneş hücrelerinde bulunan baraların geliştirilmesi ve araştırılmasına katkı sunulmasının sağlanmasıdır. Söz konusu baraların malzeme yapısının incelenmesinin yanı sıra güneş hücrelerinde oluşan mikro çatlaklara oluşumuna ve ısının etkisi çalışılması gereken alanlardan biridir. Günümüzde yaygın olarak güneş panellerinde 2 veya 3 baralı güneş hücreleri kullanılmaktadır. Bunun yanı sıra esnek güneş hücreli güneş paneli uygulamaları da bulunmaktadır. Gelişen teknoloji hücrelerde kullanılan baraların arttırılmasını ve böylece kayıpların azaltılarak verimin artmasını hedeflenmektedir. Bu amaçla 5 bara'dan (5BB) oluşan hücreler günümüzde güneş hücreleri ve modül tasarımındaki en büyük trendlerden biridir. SOLARWORLD ve TRINA SOLAR gibi birçok büyük üretici $5 \mathrm{BB}$ ön taraf kontakları olan güneş hücrelerini üretmeye başlamıştır. Artan bara sayısı ile baralar arasındaki mesafenin daha azalması ve böylece dahili direnç kayıplarını azaltılması mümkündür. 5BB'lı güneş hücresindeki alanını arttırsa da genel performans1 $2 \mathrm{BB}$ veya $3 \mathrm{BB}$ hücrelerinden daha iyi olduğu belirtilmektedir. Bara sayısının artması direnç kayıplarının ve mikro çatlakların azalmasına da katkı sağlamaktadır. Mikro çatlaklar tipik olarak baralar arasında oluştuğundan bu çatlakların etkisi iki baradan daha küçük etkilenen hücre dilimlerine doğru azaltılır. $\mathrm{Bu}$ nedenle, $2 \mathrm{BB}$ ve $3 \mathrm{BB}$ güneş hücreleriyle karşılaştırıldığında mikro çatlaklarda çoklu baralı güneş hücresinin uzun vadeli güvenilirliği daha yüksektir. Ayrıca, maliyet yönünden de daha ince çubuklu çok çubuklu tasarım, pahalı gümüş macunu kullanılmasında azalmaya yol açmaktadır.

$V_{t}=\frac{N_{s} K T}{q}$

Konu ile ilgili yapılan çalışmalara bakıldığında, güneş hücresinin tasarımı için güneş hücresi ön elektrodu için yaygın olarak kullanılan 3 baralı tasarım yerine daha fazla bara kullanımı tartışılmıştır [1]. Simülasyonlar, çok baralı tasarımının 3 baralı güneş hücresi tasarımına kıyasla daha yüksek hücre ve modül verimliliğine izin verdiğini ve aynı zamanda ön elektrot için gerekli olan gümüş miktarını azalttığını göstermiştir. Çok baradan oluşan güneş hücrelerinin ön temas için geleneksel bir tam alan Al BSF ve standart ekran baskısı kullanılmış ve $\% 19,5$ 'e varan etkinliklere ulaşılmıştır. Güneş hücreleri ve modül olarak analizler yapılmış ve çok baralı hücresi tasarımı kullanılarak ön elektrot için \%50'nin Ag tüketiminde bir azalma sağlandığ 1 ve $\mathrm{Ag} / \mathrm{Al}$ pedlerini lehimleme işlemi için kalay 
pedleri ile değiştirerek ilave bir gümüş indirimi sağlandığı görülmüştür. Güneş hücrelerinin tasarımında önemli ölçüde metalizasyon maliyetlerini düşürdüğü ve aynı zamanda verimliliği arttırdığı görülmektedir. Yapılan bir diğer çalışmada çok baralı güneş pillerinin ayrıntılı tasarımı incelenmiştir ve literatürde yapılan çalışmalar ile ilgili ayrıntılı analiz yapılmıştır [2]. Birbirine bağlı güneş hücrelerinin toplam seri direncini azaltmak için baraların sayısının değiştirilerek uygulanması kolay bir hücre tasarımı araştırılmıştır [3]. Bu çalışmada cihazın optimum verimliliğini belirlemek için iki diyotlu modele dayalı bir simülasyon programı uygulanmıştır. Ayrıca, simülasyonlar çoklu baralara sahip bir cihazın ön yan metalizasyon için metal tüketiminde bir azalma nedeniyle maliyet tasarrufunda yüksek bir potansiyele sahip olduğunu ortaya koymuştur. Optimize edilmiş bir hücre yapısı için, yeterli bir ön yan metalizasyon için gereken Ag macunu miktarı, 26 mm'lik bir güneş hücresi için $7 \mathrm{mg} \quad \mathrm{Ag}$ macununa indirgenebildiği gösterilmiştir. Aynı zamanda verimliliğin de arttırılabildiği görülmüştür. Cephe yüzü tasarımı için yaygın olarak kullanılan üç bara tasarımından daha fazla sayıda barayı kullanan bir ön taraf tasarımı tartışılmıştır [4]. Gerekli kabloların sayısını ve geometrisini optimize eden bir modülde her katılımcının seri dirençlerini özetlemek için iki diyotlu modele dayalı bir simülasyon tasarım beş baradan (4S-5BB) oluştuğu için, 3BB'ye ( 129 mg) göre daha az ön gümüş metali ( 73 mg) kullanır, bu nedenle maliyet düşer. Ek işleme basamağı olmaksızın metalizasyon 4S-5BB tasarımı, endüstriyel boyut için $>\% 20$ verim elde etmek için büyük bir potansiyel gösterilmiştir. \%19,3'lük 3BB muadili ile karşılaştırıldığında ortalama verimlilik \%19,66 olan 4S-5BB endüstriyel Al-BSF hücresi için ön sonuç sunulmuştur. Çoklu baralı güneş hücresinin Flekso-grafik bir rulo-düz makinede temel baskı testleri gerçekleştirilmiştir [8]. Deneysel bir anilox rulo ve elastomerik lazer gravür baskı plakaları kullanılmıştır. Ara kurutma adımlı çift baskı yöntemi uygulanmıştır. Bunu kullanarak, $33 \mu \mathrm{m}$ genişliğe ve $8 \mu \mathrm{m}$ yüksekliğe kadar olan kontak parmakları gerçekleştirilmiştir. 500-1500 $\Omega / \mathrm{m}$ aralığında yanal direnç dört nokta ölçüm yöntemiyle belirlenmiştir. Bu sonuçlar çok baralı güneş hücrelerinin ince hat metalizasyonu için flekso-grafik bask1 kapasitesinin özelliğini arttırdığını göstermiştir. Sonlu Elemanlar Metodu (FEM) temel alınarak bir model oluşturulmuştur [9]. Bir tarafa bağlı Multi Busbar (MBB) düzenine sahip bir silikon solar hücrenin bir bölümünün deformasyonu üzerindeki önemli ara bağlayıcı özelliklerin etkisi gösterilmiştir. Telin çapı, hücre deformasyonunu en büyük etki eden faktörlerden biridir. Bununla birlikte eğer tel çap1 da değiştirilirse, bir bütün MBB güneş pilinin ara bağlantısı için tel sayısı da adapte edilmesi gerekliliği görülmüştür. Üstelik, Young modülünün ve hücre üzerindeki bakır telin akma direncinin önemli etkileri de görülmektedir. Ek olarak, her iki tarafa bağlı olan bir MBB güneş pilindeki termomekanik stres dağılımını belirleyen bir FEM modelinin sonuçları gösterilmektedir. Bağlantı tellerindeki gerilme dağılımı lehim prosesinden sonra oda sicaklığına soğutma sırasında plastik deformasyona uğradığını ortaya koymaktadır. Ag ve Ag LIP yaklaşımını kullanan ileri bir ön yan metalleştirme tekniği, Ag tüketimini $32 \mathrm{mg} /$ hücre kadar düşük değere daha da azaltma potansiyelini gösterirmiştir. Güneş hücresindeki baraların sayısı arttıkça $\mathrm{Ni} / \mathrm{Cu} / \mathrm{Ag}$ kaplama işleminin avantajlarını ortaya konulmuştur [6]. Dört ve beş baralı güneş hücreler işlenerek, verimlilik ve lehim yapışması açısından üçlü olanlarla karşılaştırılmıştır. Bara sayısı 3 'ten 4'e veya 5'e çıkarıldığında lehim yapışması çoğunlukla $1 \mathrm{~N} / \mathrm{mm}^{2}$ 'den daha fazla kalırken verimlilik \%0,15 oranında artmıştır. Biriken metal kütlesi, 5 BB'da, 3 BB kıyasla \%30'a kadar düşürülebilirmiştir. $\mathrm{Bu}$ çalışmada yenilikçi bir tasarımını ortaya konulmuştur [7]. Çok baralı güneş pilleri tasarımları ve modüller, güneş hücreleri, modül performansı ve Ag metal tüketimi ile karşılaştırılmış ve değerlendirilmiştir. Monte edilmiş çok bara güneş hücreleri ve dört hücreli modüller endüstriyel tip üç çubuklu güneş hücreleri ve modül seviyesinde $\% 0,6$ abs'lik ortalama doldurma faktörü kazançları gösteren modüller ile karşılaştırılmıştır. Bir Bunlar; Metal gölgelendirme azaltılması, Kısa devre akımını 
(JSC) arttırılması, Açık devre voltajı (VOC), Doldurma faktörünün muhafaza edilmesi ve Endüstriyel bir Al arka yüzey alanı (Al-BSF) güneş hücresinin etkinliğinin arttırılmasıdır. plaka teknikleri kullanılarak gümüşün $\% 89$ 'dan fazla bir azaltılması sağlandığı gösterilmiştir. Başka bir çalışmada çok baralı güneş hücrelerinin ve seçici emitörlü modüller ince çizgi baskılı ön yüzey metalizasyonu ve tam alüminyum arka tarafla ilgili ayrıntılı bir genel bakış sunulmuștur [5]. Üç baralı ve Ön yan veya mbb güneş hücre arka tarafinda bir yastık grubu üzerinde ped sıranın en diş ped bitişik yaklaşı1k $162 \mathrm{MPa}$ teller, maksimum çekme gerilimi değerleri belirler. Buna ek olarak, silikon güneş pilinde büyük Çok baralı güneş pil tasarımının modül verimliliğini $\% 0,5$ oranında $\operatorname{arttırdığ1~ve~tohum~ve~uzunluğunun~}$ azaltılmasından kaynaklandığını ortaya koyarak hücre tasarımı için yeni olanaklar ortaya çıkarmıştır. Bu alanlar silikon çatlaklar veya ped metal kaplamanın programı kullanılmıştır. Simülasyonlar, çok baralı tasarımın avantajlarının etkin parmak yapışkan arızaları gibi kusurlara en duyarlı olmasını beklenmektedir.

Bara temas geometrisine sahip IBC firması tarafından üretilen güneş pilleri alanının arttırılması, daha uzun parmakların kullanılmasını gerektirir. Metalizasyon kalınlığ sabit tutulursa parmak direnci artacağı gözlenmiş̧ir [10]. İnce bir metalleşmeyi muhafaza etmek için, kontak başına baraların sayısını artırmak faydalı olduğu görülmüştür. Bununla birlikte, her polarite için birden fazla baranın kullanılması asimetrik kontak geometrisini ifade eder. Sonuç olarak, çalışma esnasında aynı kutup baraları farklı akımlar taşır. Kaçınılmaz elektrik dirençlerindeki voltaj düşüşlerinden dolayı, bu, bu baralar arasında belirgin bir potansiyel farklılığa neden olabilir. Akım-voltaj karakteristikleri genellikle voltaj ölçümü için ayrı duyu kontakları kullanılarak ölçülür olduğundan, bu kontakların konumu ve sayısı sonuçtaki akım-voltaj karakteristiğinin şeklini ve dolayısıyla dolum faktörünü önemli ölçüde etkiler. Devre simülatörü LTSpice ile simülasyonlar yoluyla lehimli tırnaklarla kalıcı temasın dolum faktörünün doğru bir şekilde belirlenmesine izin verdiğini gösterilmektedir. Geçici temas için kullanılan bir mandren, doldurma faktörü hatasını mutlak $\% 0,5$ 'in altına düşürmek için bar başına her bir en az bir duyu kontağı ve $30 \mathrm{~m} \Omega$ 'un altındaki pin kontak direnci içermelidir. Güvenilir lehim bağlantılarını sağlamak için kızı̈ötesi lehimleme ve ön metalizasyon tasarımının optimizasyonu ile Multi Busbar hücrelerinin (MBB) ara bağlantısı bu çalışmada incelenmiştir [11]. Homojen bir radyasyon alanı, Prosese uyarlanmış bir alt tutucu cihaz, Homojen bir tel kaplama, Hassas tel konumlandırma ve yükselen lehim sıcaklıklarından kaynaklanan tel genleşmesini emmek MBB ara bağlantı süreci için çok önemlidir. Kabuk kuvvetlerini, 160 lehimli ped içeren iki MBB hücresinin merkezine ait beş ped sırasının ortalama siyırma kuvveti değeri olarak 5,7 N/mm'ye kadar ölçülmektedir. Ayrıca bir tek hücreli MBB modülü, 3-BB modülüne kıyasla yaklaşık olarak $0,3 \Omega / \mathrm{cm}^{2}$ daha düşük seri direnç ile daha homojen bir seri direnci göstermektedir; bu da karanlık doygunluğun akısı ve seri direnci ölçüm yönetimi ile belirlemiştir. Son olarak, otomatik bir MBBstringer ile üretilen iki adet 20 hücreli MBB modülü, IV, EL ve modül optik görünümünde önemli değişiklikler olmaksızın TC-200 testini geçtiği görülmüştür.

\section{PERFORMANS ANALIZİ}

$\mathrm{Bu}$ çalışmada, farklı ışınım şiddetinde güneş hücresindeki baraların sayısının elektik verimine olan etkisi MATLAB programı ile teorik olarak yapılmış ve sonuçlar deneysel çalışma ile karşılaştırılmıştır. Deneyse çalışma flash test olarak adlandırılan ve $2 \mathrm{~m} \times 1 \mathrm{~m}$ boyutlarında güneş panellerinin $\mathrm{I}-\mathrm{V}$ Curve, $\mathrm{P}-\mathrm{V}$ eğrisi ve diğer parametrelerinin belirlendiği cihazda yapılmıștır. Farklı 1şınım şiddetine göre ayarlanan cihazla MATLAB benzetim sonuçları karşılaştırılmıștır. Şekil 4'de performans analizinin yapıldığ 1 deneysel düzenek ve MATLAB benzetimi görülmektedir. Deneysel çalışmalarda ortam sicaklığ $124{ }^{\circ} \mathrm{C}$ sabit tutulmuştur. Böylece, güneş hücresine sadece baraların etkisini incelenmesi sağlanmıştır. 


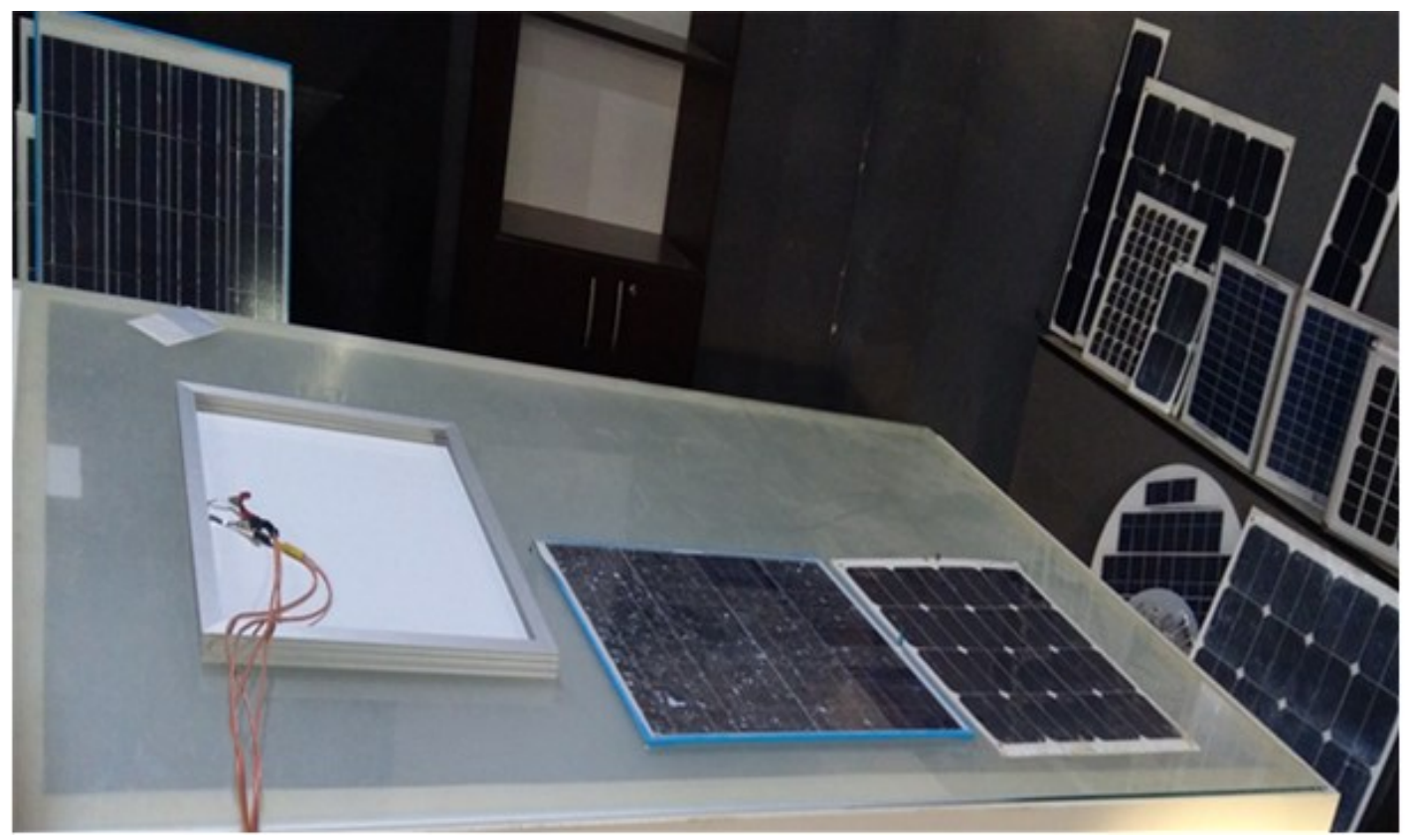

(a)

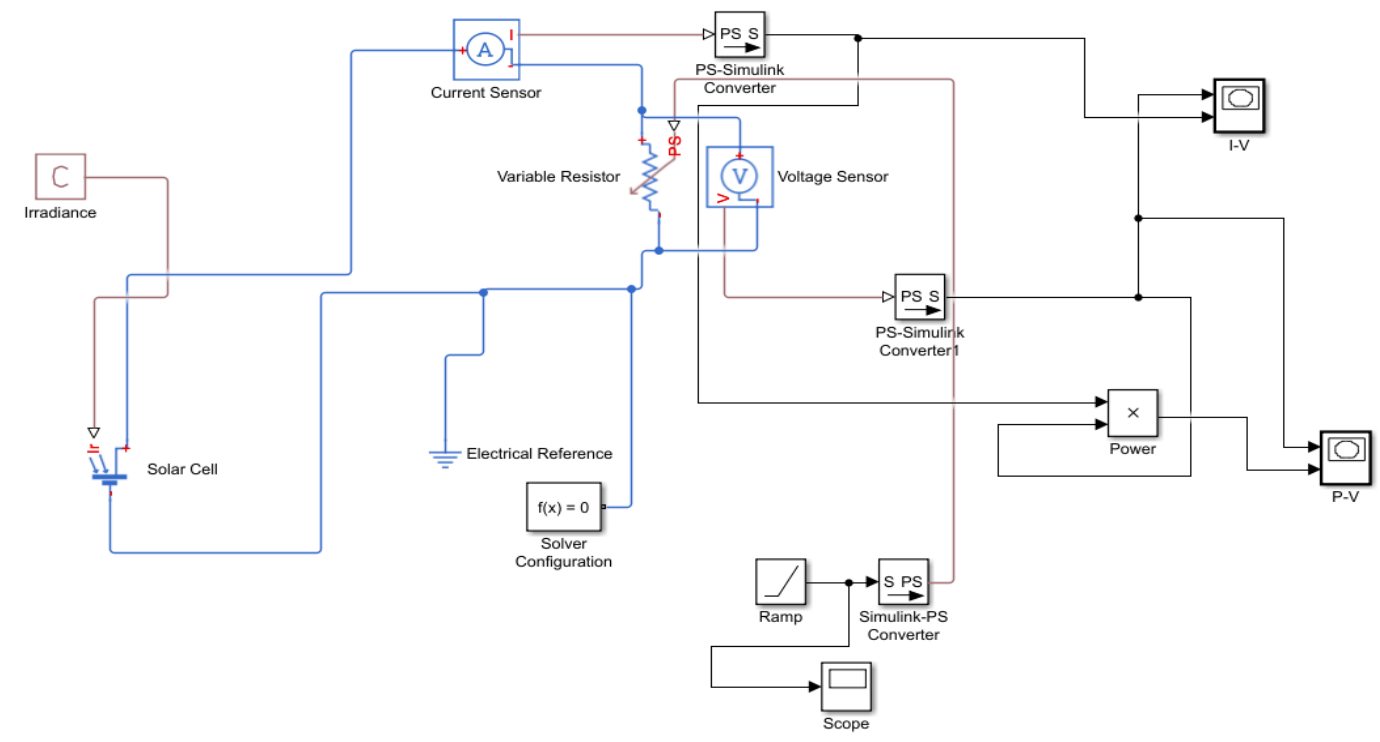

(b)

Şekil 4. a) Deneysel düzenek b) Benzetim çalışması

Şekil 5 (a-h)'te MATLAB programı ile yapılan benzetim çalışmasının sonuçları verilmektedir. $\mathrm{Bu}$ grafikler 2BB-3BB-4BB ve esnek panellerin farklı ışınım şiddetlerinde I-V eğrilerini göstermektedir.
Panel tasarımı yapılırken bu eğriler dikkate alınır. $\mathrm{Bu}$ eğriler sonucunda panelin uygun değer koşulda çalışırken maksimum güç üretimi hesaplanmış olur. 


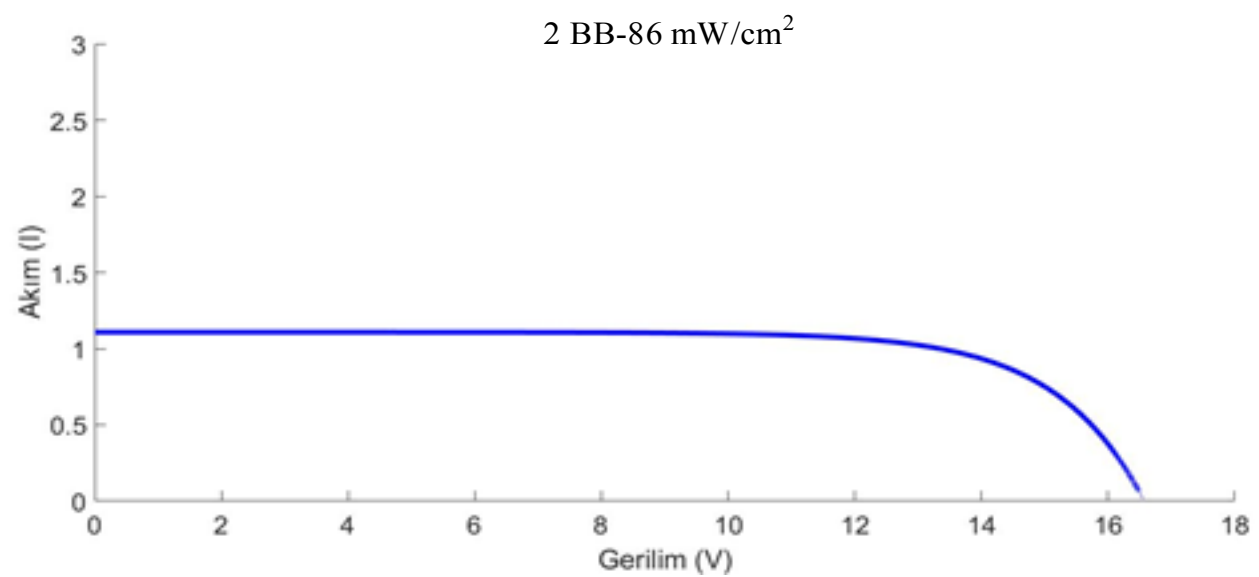

(a)

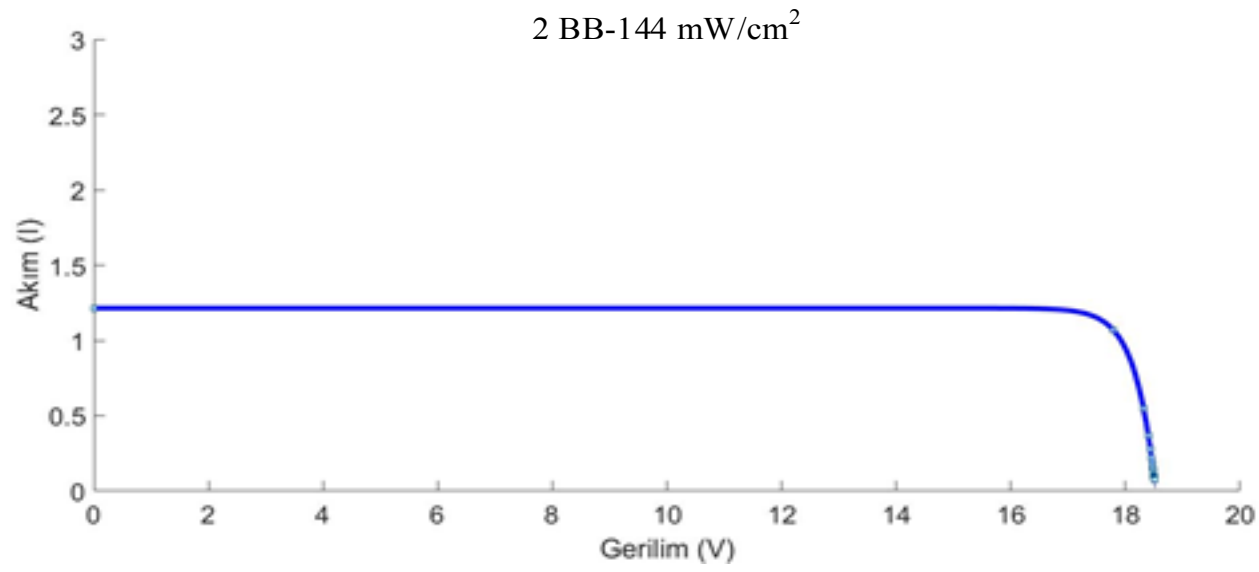

(b)

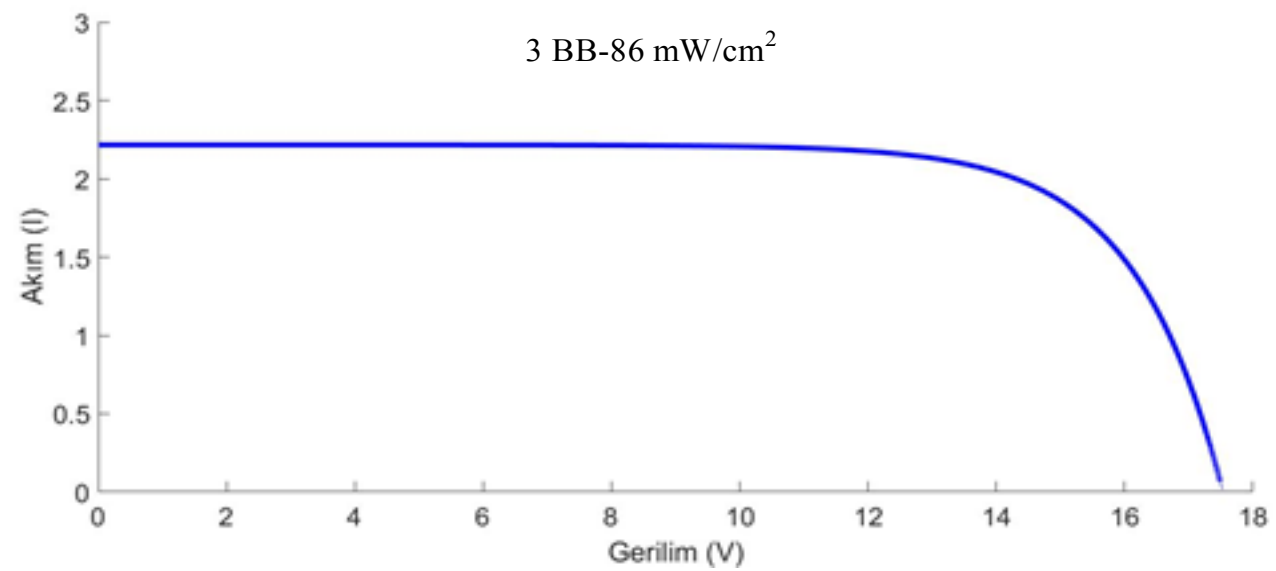

(c)

Şekil 5. MATLAB programı ile yapılan benzetim sonuçlar $\mathrm{mW} / \mathrm{cm}^{2}$, (c) $3 \mathrm{BB}-86 \mathrm{~mW} / \mathrm{cm}^{2}$

(a) $2 \mathrm{BB}-86 \mathrm{~mW} / \mathrm{cm}^{2}$, (b) $2 \mathrm{BB}-144$ 


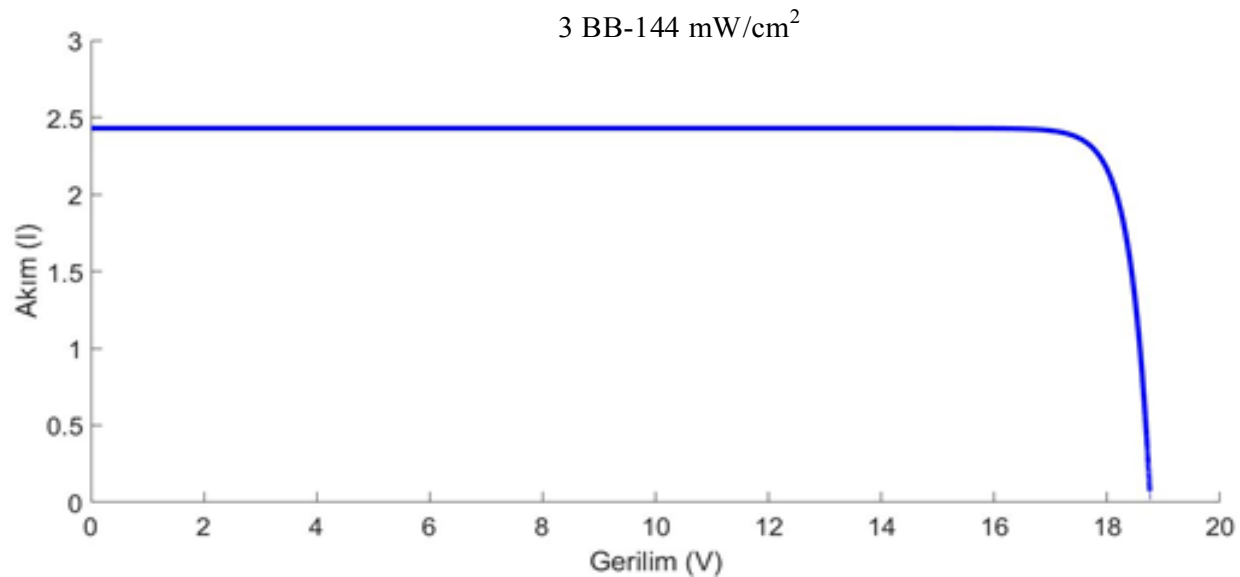

(d)

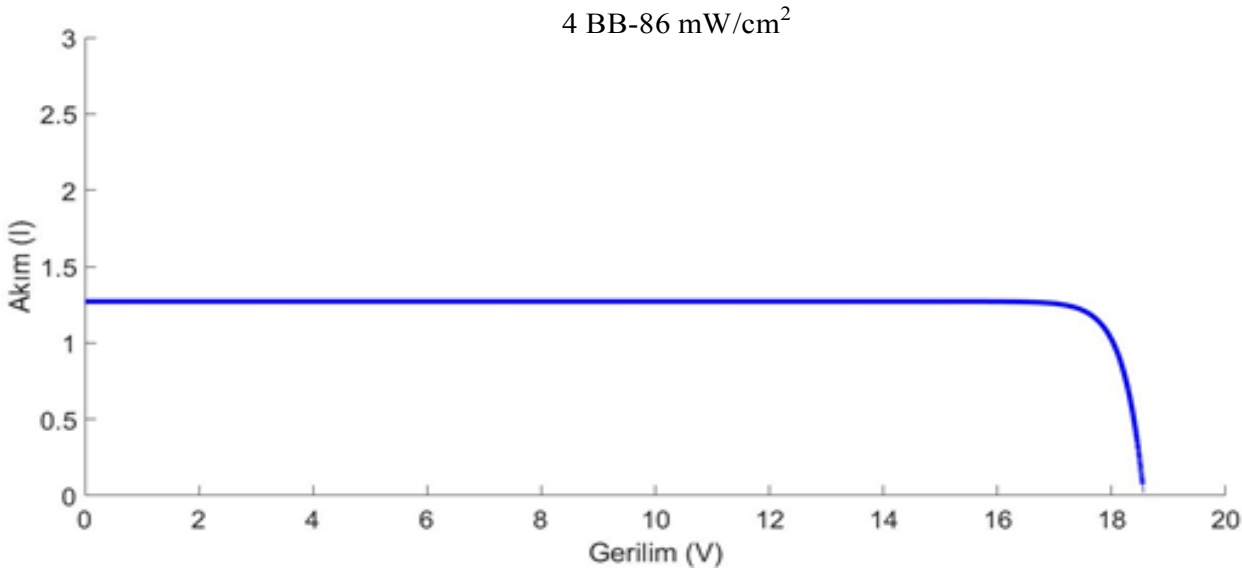

(e)

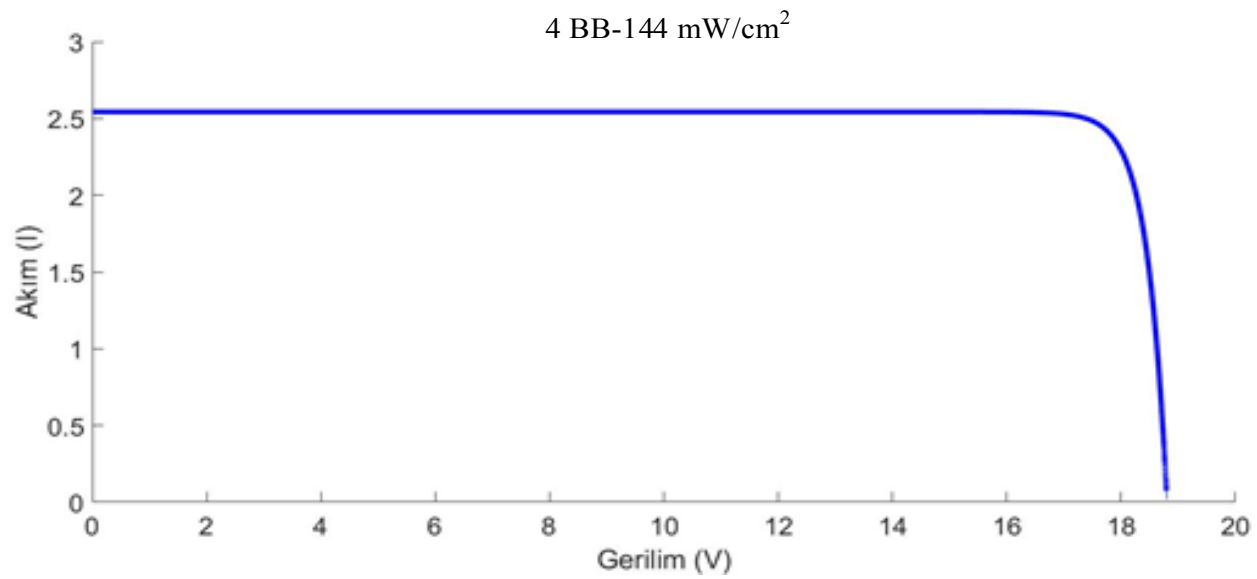

(f)

Şekil 5. MATLAB programı ile yapılan benzetim sonuçları, (d) 3 BB-144 mW/cm², (e) 4 BB-86 $\mathrm{mW} / \mathrm{cm}^{2}$, (f) 4 BB-144 $\mathrm{mW} / \mathrm{cm}^{2}$ 


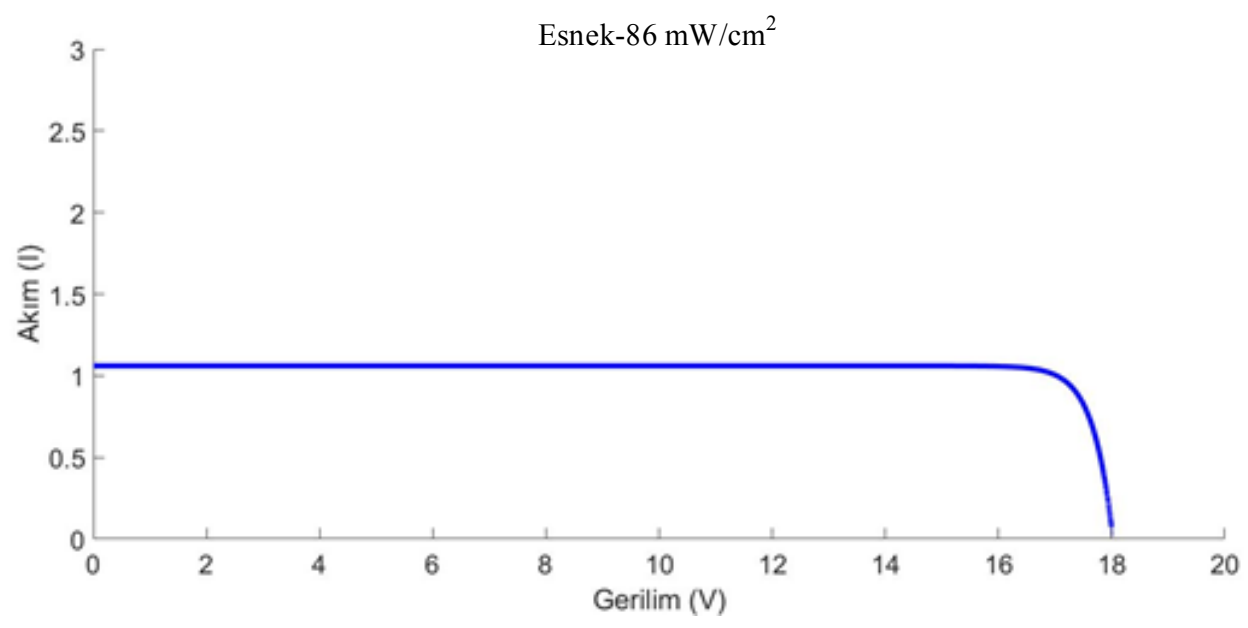

$(\mathrm{g})$

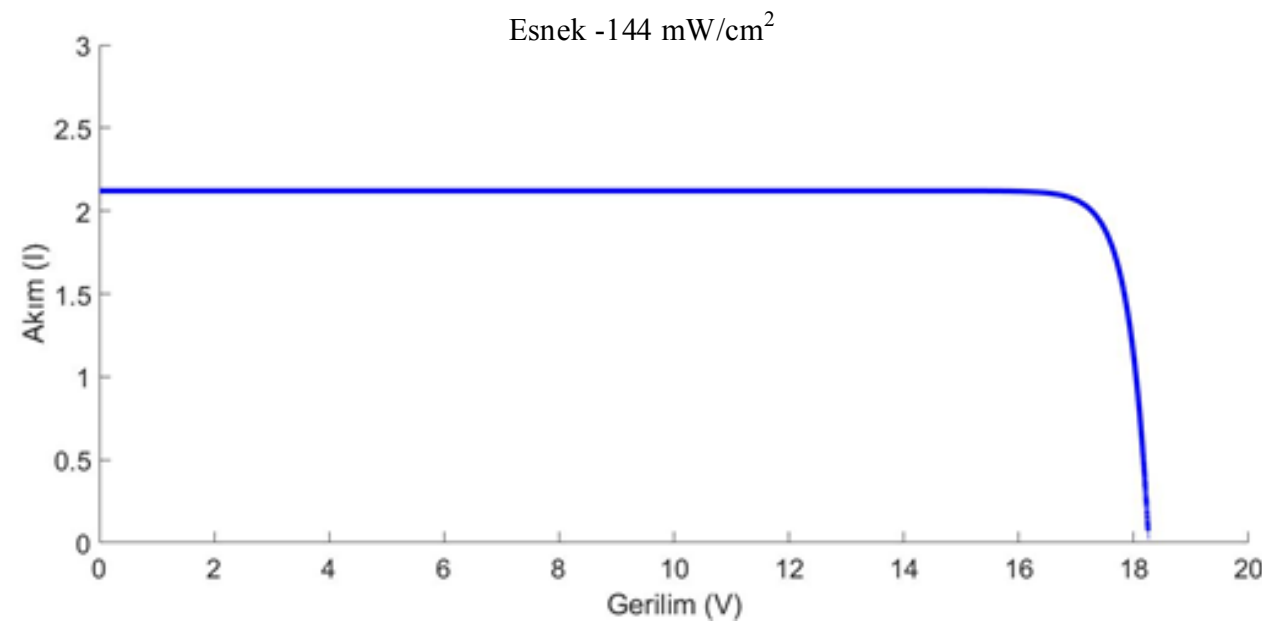

(h)

Şekil 5. MATLAB programı ile yapılan benzetim sonuçları, (g) Esnek- $86 \mathrm{~mW} / \mathrm{cm}^{2}$, (h) Esnek -144 $\mathrm{mW} / \mathrm{cm}^{2}$

2BB-3BB-4BB ve esnek panelin için yapılan benzetim çalışmaları deneysel çalışmada kullanılan 1şık şiddetlerine göre yapılmıştır. Sonuçları karşılaştırmak için 144 ve $86 \mathrm{~mW} / \mathrm{cm}^{2}$ 1şınım şiddetlerindeki benzetim sonuçları verilmiştir. Şekil 6'de $144 \mathrm{~mW} / \mathrm{cm}^{2}$ ile $126 \mathrm{~mW} / \mathrm{cm}^{2}$ arasında değişen 1 ş1k şiddeti göre 2BB-3BB-4BB-Esnek baralı güneş hücrelerinin deneysel performans analizi verilmiştir. Şekil 7'de $124 \mathrm{~mW} / \mathrm{cm}^{2}$ ile 106 $\mathrm{mW} / \mathrm{cm}^{2}$ arasında değişen 1 şı şiddeti göre 2BB-3BB-4BB-Esnek baralı güneş hücrelerinin deneysel performans analizi verilmiştir. Şekil 8'de $104 \mathrm{~mW} / \mathrm{cm}^{2}$ ile $86 \mathrm{~mW} / \mathrm{cm}^{2}$ arasında değişen 1şınım şiddeti göre 2BB-3BB-4BB-Esnek baralı güneş hücrelerinin deneysel performans analizi verilmiştir. $\mathrm{Bu}$ üç performans analizine bakıldığında değişen 1şınım şiddetinde ve değişen bara sayısı incelendiğinde üretilen gücün bara sayısı artıkça artış olduğu gözlenmiştir. Işınım şiddeti değişiminde bile bara sayılarına göre kıyaslandığında bara sayısı arttıkça yine veriminin artığı görülmektedir. 

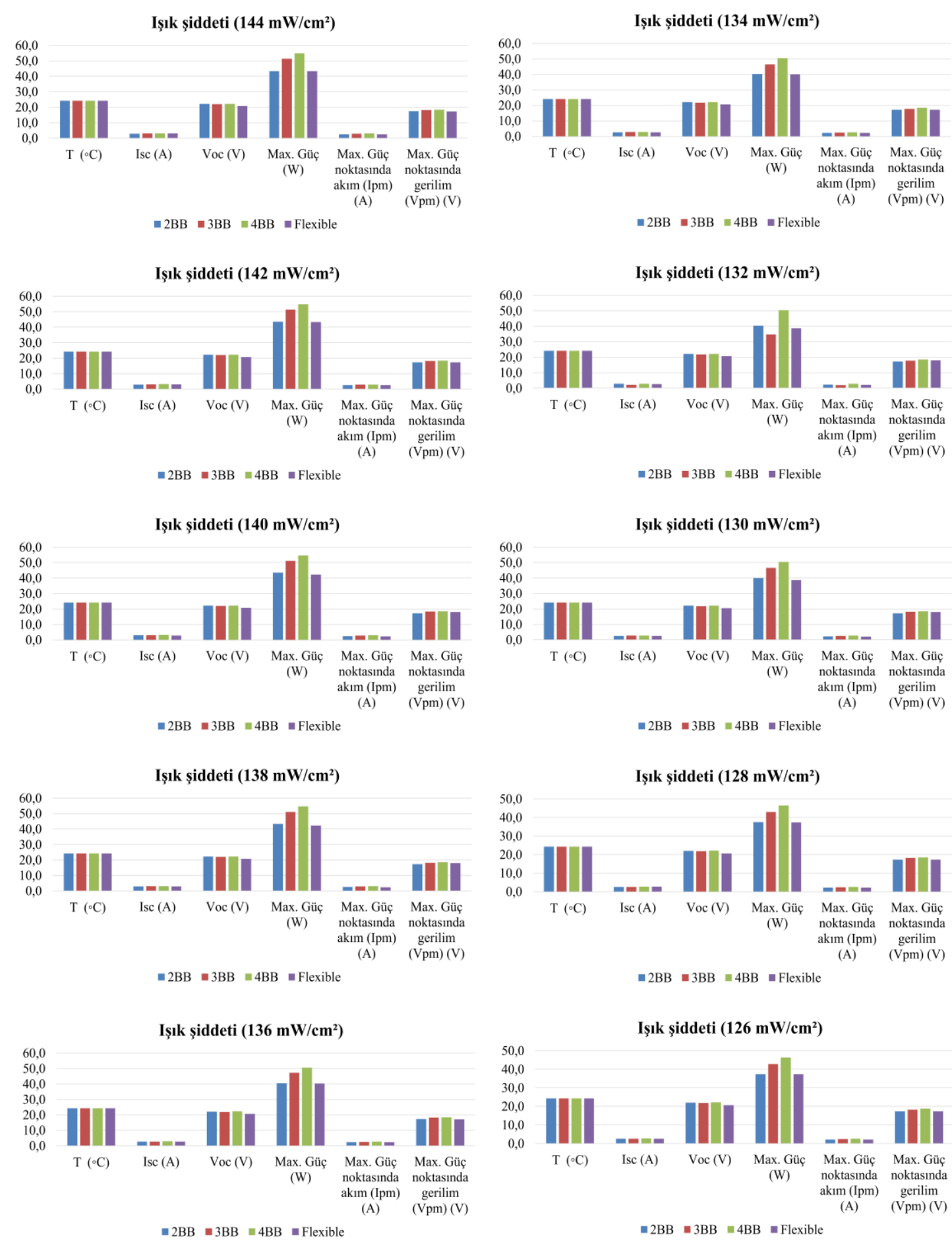

Şekil 6. 144-126 mW/ $\mathrm{cm}^{2}$ 1şınım şiddeti değişimine göre 2BB-3BB-4BB-Esnek performans analizi 


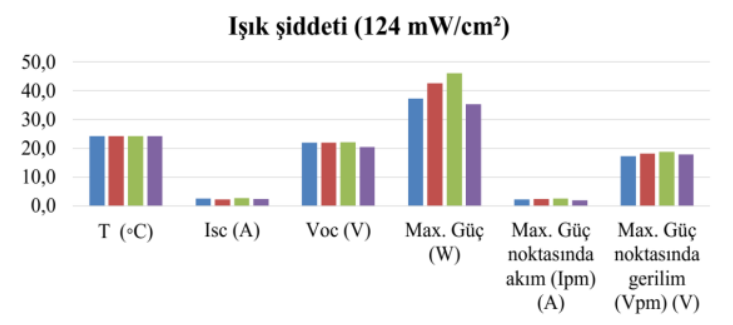

$\| 2 \mathrm{BB}=3 \mathrm{BB}=4 \mathrm{BB}=$ Flexible

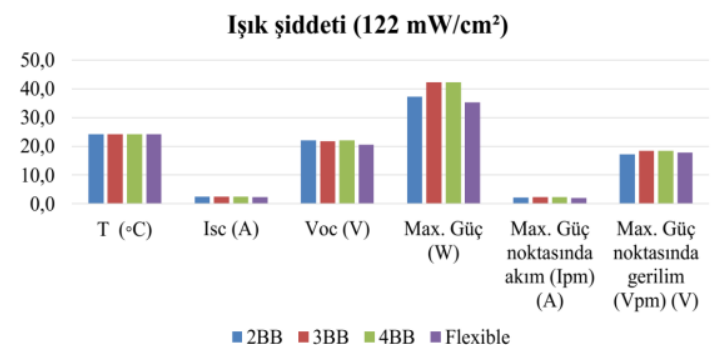

Işık şiddeti $\left(120 \mathrm{~mW} / \mathrm{cm}^{2}\right)$

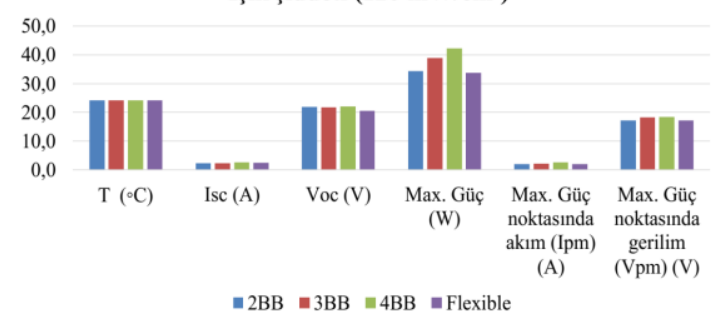

Işık şiddeti $\left(118 \mathrm{~mW} / \mathrm{cm}^{2}\right)$

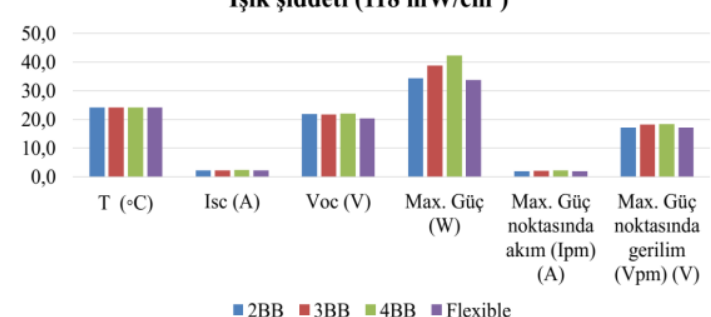

Işık şiddeti $\left(116 \mathrm{~mW} / \mathrm{cm}^{2}\right)$

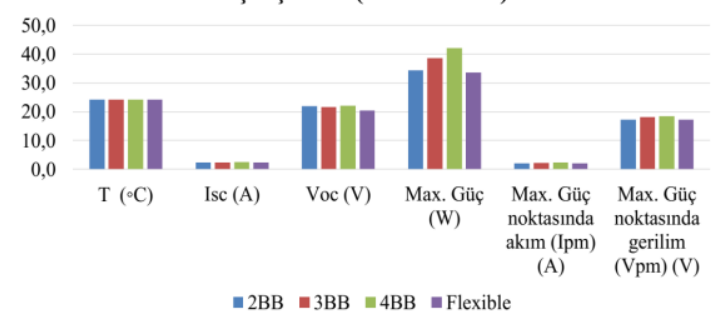

Şekil 7. 124-106 mW/ $/ \mathrm{cm}^{2}$ 1şınım şiddeti değişimine göre 2BB-3BB-4BB-Esnek performans analizi
Işık şiddeti $\left(114 \mathrm{~mW} / \mathrm{cm}^{2}\right)$

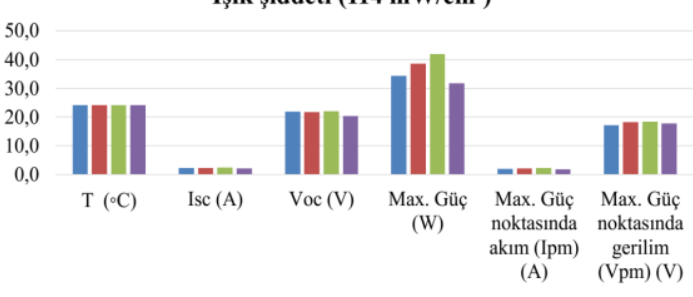

$\approx 2 \mathrm{BB}=3 \mathrm{BB}=4 \mathrm{BB} \approx$ Flexible

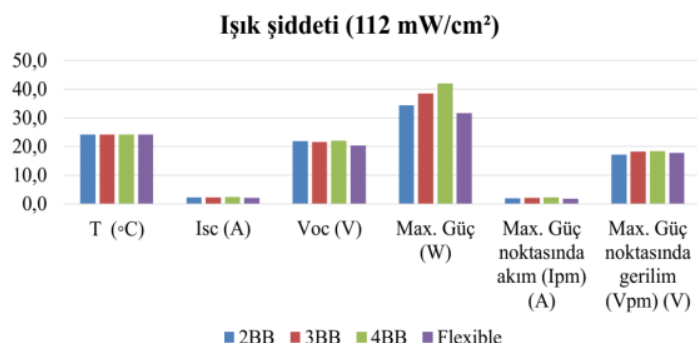

Işık şiddeti $\left(110 \mathrm{~mW} / \mathrm{cm}^{2}\right)$

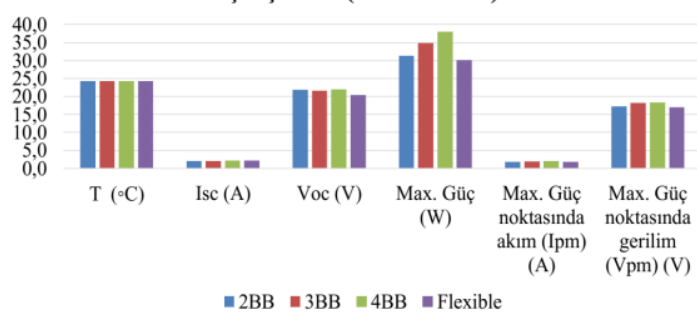

Işık şiddeti $\left(108 \mathrm{~mW} / \mathrm{cm}^{2}\right)$

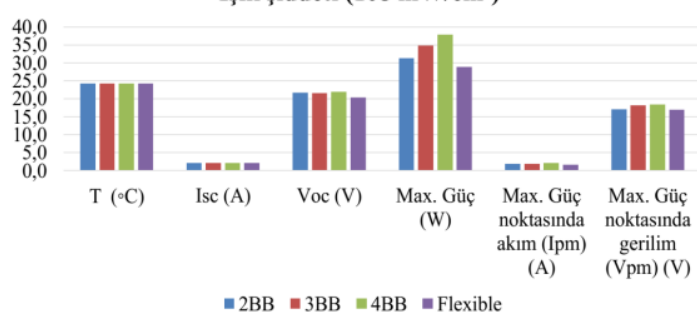

Ișık șiddeti $\left(106 \mathrm{~mW} / \mathrm{cm}^{2}\right)$

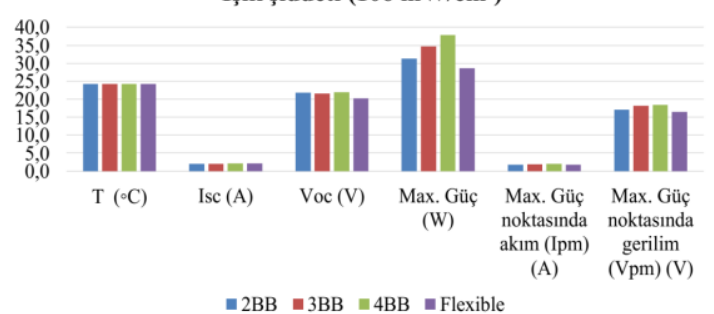


Issk șiddeti $\left(104 \mathrm{~mW} / \mathrm{cm}^{2}\right)$

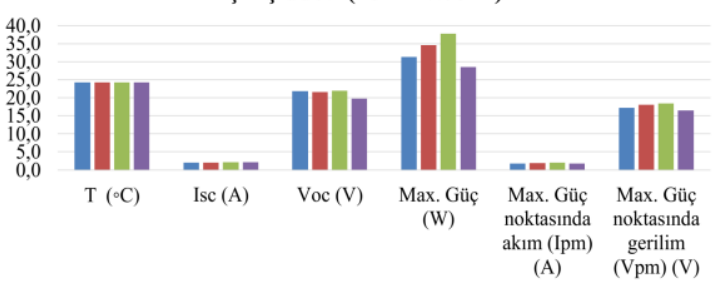

$\because 2 \mathrm{BB}=3 \mathrm{BB}=4 \mathrm{BB}=$ Flexible

Ișık șiddeti $\left(102 \mathrm{~mW} / \mathrm{cm}^{2}\right)$

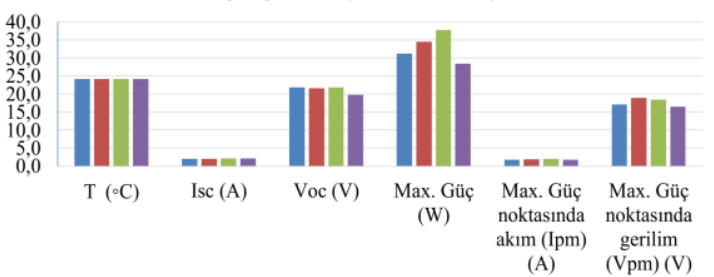

$\because 2 \mathrm{BB}=3 \mathrm{BB}=4 \mathrm{BB}=$ Flexible

Ișık șiddeti $\left(100 \mathrm{~mW} / \mathrm{cm}^{2}\right)$

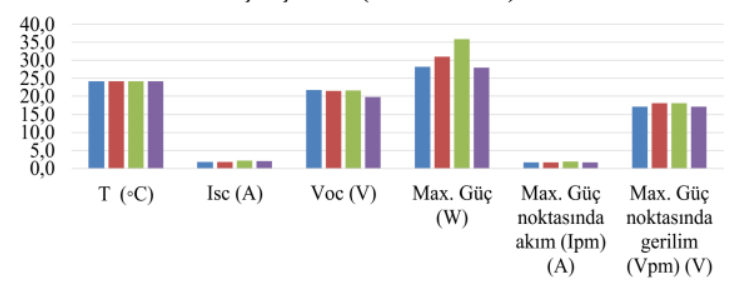

$\because 2 \mathrm{BB}=3 \mathrm{BB}=4 \mathrm{BB}=$ Flexible

Ișık șiddeti $\left(98 \mathrm{~mW} / \mathrm{cm}^{2}\right)$

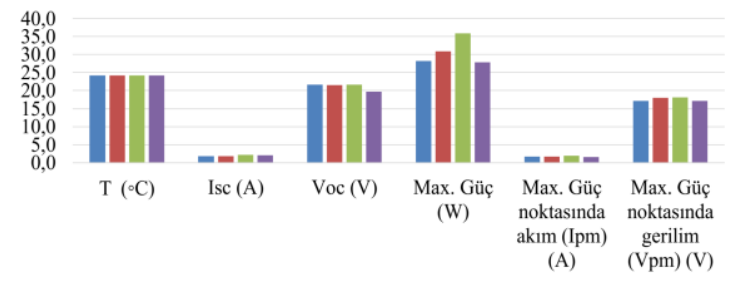

$\approx 2 \mathrm{BB} \approx 3 \mathrm{BB}=4 \mathrm{BB} \approx$ Flexible

Ișık șiddeti $(96$ mW/cm²)

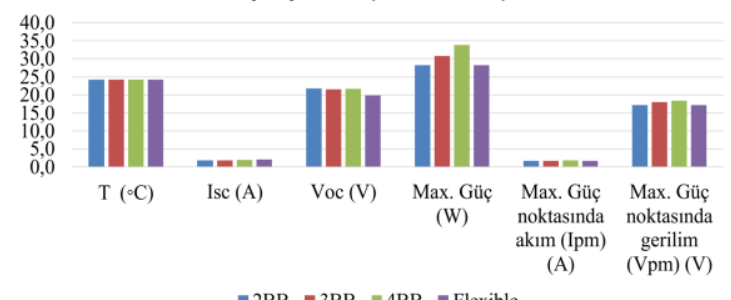

Ișı șiddeti $\left(94 \mathrm{~mW} / \mathrm{cm}^{2}\right)$

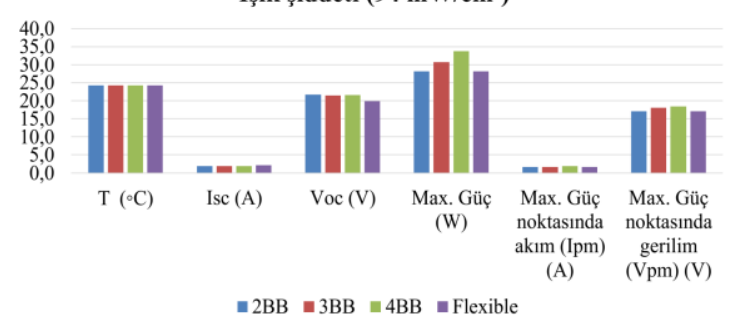

Işık şiddeti $\left(92 \mathrm{~mW} / \mathrm{cm}^{2}\right)$

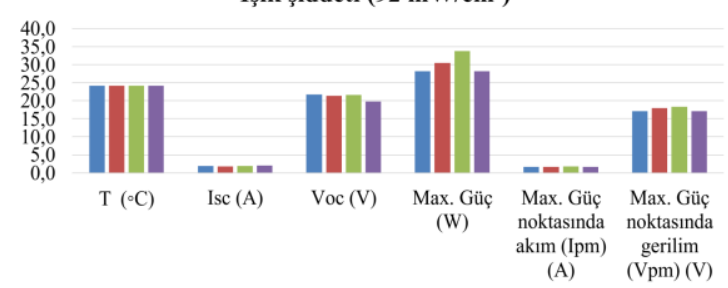

=2BB $=3 \mathrm{BB}=4 \mathrm{BB}=$ Flexible

Işık şiddeti $\left(90 \mathrm{~mW} / \mathrm{cm}^{2}\right)$

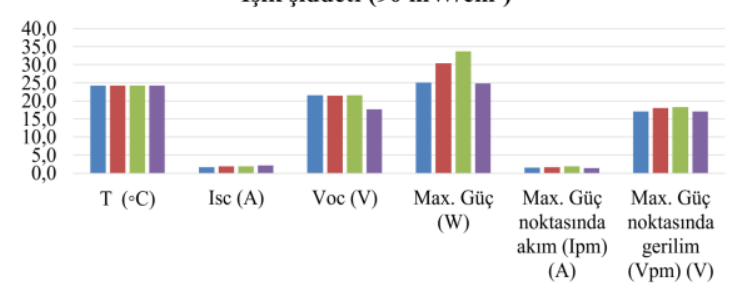

$\approx 2 \mathrm{BB}=3 \mathrm{BB}=4 \mathrm{BB}=$ Flexible

Işık şiddeti $\left(88 \mathrm{~mW} / \mathrm{cm}^{2}\right)$

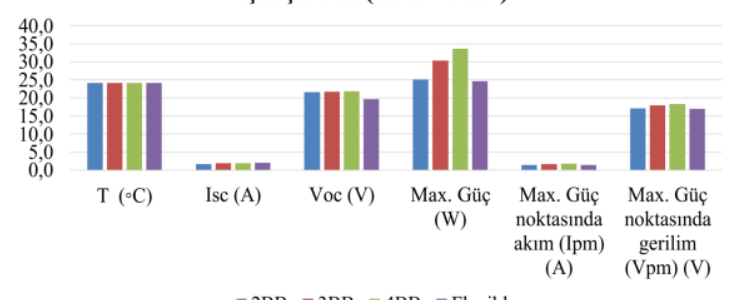

= $2 \mathrm{BB}=3 \mathrm{BB}=4 \mathrm{BB}=$ Flexible

Ișık șiddeti $\left(86 \mathrm{~mW} / \mathrm{cm}^{2}\right)$

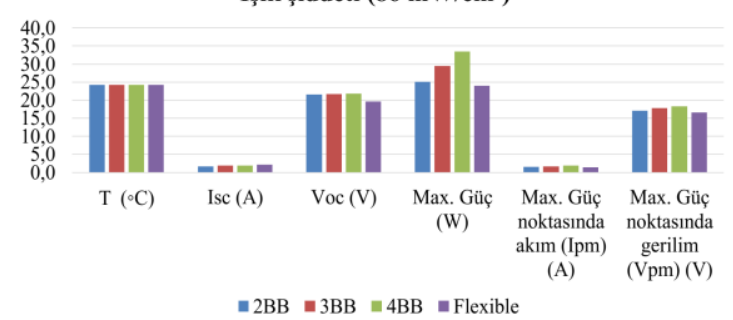

Şekil 8. 104-86 mW/ $/ \mathrm{cm}^{2}$ 1şınım şiddeti değişimine göre 2BB-3BB-4BB-Esnek performans analizi 


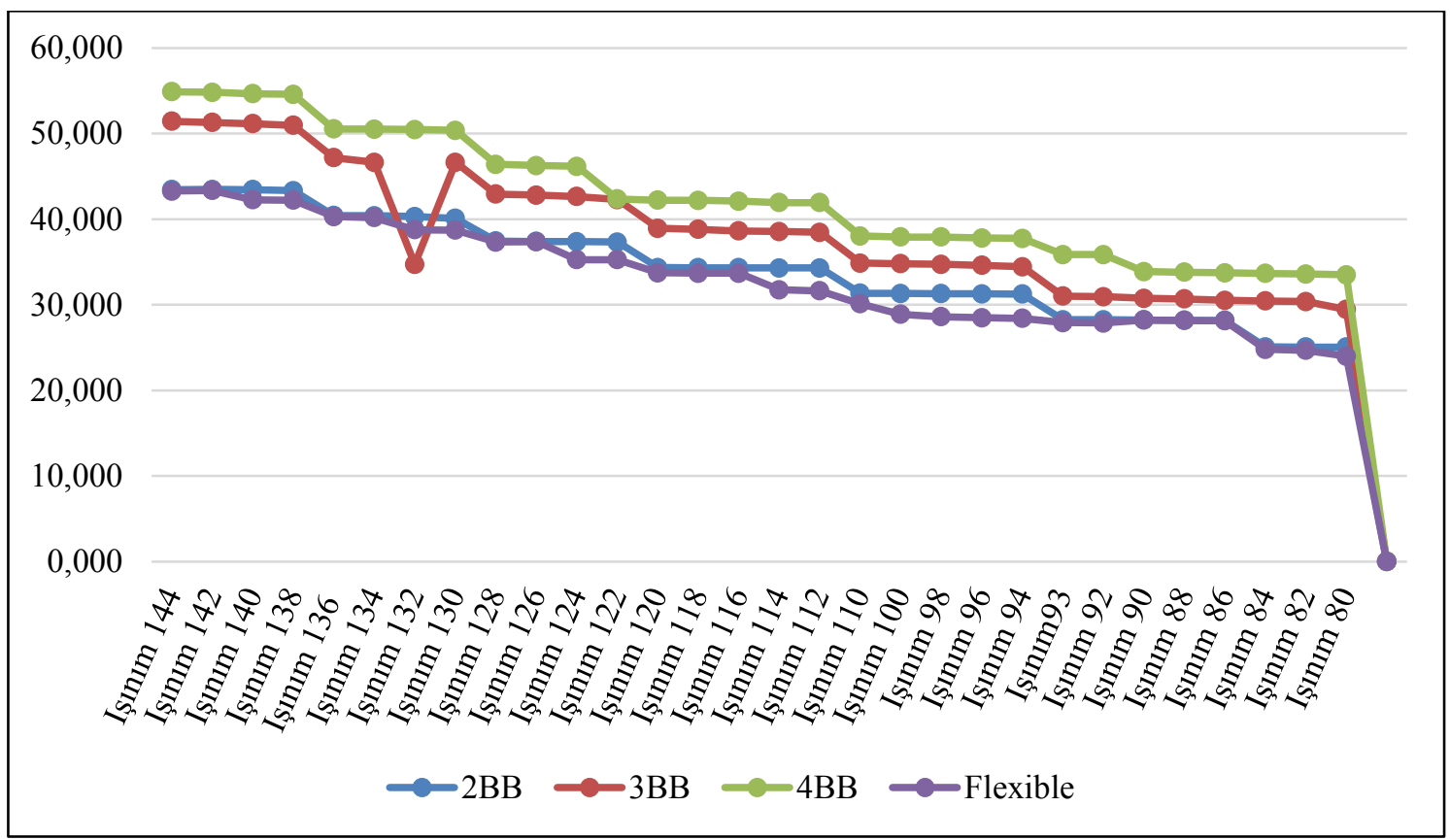

Şekil 9. Bara sayısına bağlı maksimum anlık güç değerinin ışınım ile değişimi

Benzetim çalışmaları ile deneysel çalışmanın sonuçlarına ait şekiller incelendiğinde akım ve voltaj değerlerini birbirine çok yakın olduğu görülmüştür. 2 BB'lı ve $86 \mathrm{~mW} / \mathrm{cm}^{2}$ 1şınım şiddeti için yapılan benzetim ve deneysel çalışmanın sonuçlarına bakıldığında akım değerleri sırası ile 1,1 ve 1,3 iken voltaj değerleri 16,4 ile 16,8 olarak bulunmuştur. $144 \mathrm{~mW} / \mathrm{cm}^{2}$ 1şınım şiddeti için akım değerleri 2,3 ile 2,45, voltaj değerleri 17,3 ile 17,2 bulunmuştur. 3BB'lı ve $86 \mathrm{~mW} / \mathrm{cm}^{2} 1$ șınım şiddeti için, akım değerleri 1,3 ile 1,48, voltaj değerleri ise 18,2 ile 17,$9 ; 144 \mathrm{~mW} / \mathrm{cm}^{2}$ 1şınım değeri için akım 2,4 ile 2,6, voltaj değerleri 18,8 ile 18,2 bulunmuştur. 4 BB'll ve $86 \mathrm{~mW} / \mathrm{cm}^{2}$ 1şınım şiddeti için sonuçlara bakıldığında akım değerleri 1,3 ile 1,6 voltaj değerleri 18,4 ile 18,2, $144 \mathrm{~mW} / \mathrm{cm}^{2}$ 1şınım değeri için akım değerleri 2,52 ile 2,87, voltaj değerleri 18,8 ile 18,6 bulunmuştur. Benzer sonuçlar esnek panelin sonuçlarında da gözlenmiştir. Bara sayının artması ile anlık üretilen maksimum güç eğrisi Şekil 9'da verilmiştir. Şekilden de görüldüğü üzere bara sayının artması güneş hücresinin güç üretimini artırmıştır. Yukarıdaki sonuçlardan anlaşılacağı üzere, bara (BB) sayısının artması ile elektrik verimi artmıştır.
Benzetim sonuçları ile deneysel çalışma kıyaslandığında; voltaj değerlerinde çok yakın sonuçlar elde edilirken akım değerlerinde biraz farklılık görülmektedir. Bu farklılık, seçilen direnç değerinden kaynaklanmaktadır.

\section{SONUÇLAR}

Bu çalışmada, güneş hücrelerin verimine baraların etkisi deneysel ve teorik olarak ortaya konulmuştur. Farklı baralar için yapılan deney sonuçları da göstermiştir ki, bara sayısının artmasıyla güneş hücresinin elektrik verimi artmıştır. 2BB, 3BB ve 4BB'lı güneş hücrelerinin ışınım şiddetindeki değerlerindeki akım ve voltaj değerleri baranın etkisini ortaya koymuştur. Dünya genelindeki güneş enerjisi kullanım durumuna baktığımızda ABD başta olmak üzere Avrupa ülkeleri ve Çin başı çekmektedir. Güneş enerjisini kullanan ülkelere baktığımızda bazıları güneş 1şınım potansiyeli bakımından öne çıkarken bazıları da sahip oldukları teknoloji birikimi ve enerjiye olan bağımlılığı ile öne çıkmaktadır. Güneş enerjisinden elektrik enerjisi elde etmek için en temel elemanlar güneş hücreleridir. Güneş 
panellerinin verimlerinin arttırılması için son yıllarda bara sayılarında değişikliklere gidilmiştir. $\mathrm{Bu}$ çalışmada, güneş hücresindeki baraların sayısı artmasının performansa etkisi ayrıntılı bir şekilde incelenmiştir. $\mathrm{Bu}$ çalışma sayesinde çok baralı güneş pilinin verimliliğe etkisi de açık bir şekilde görülmüştür. Ülkemizde de artık çok baralı güneş hücresine geçilmesi için gerekli düzenlemeler yapılmaktadır. Güneş hücresindeki baraların elektrik üretimine üzerine olan pozitif etkisi yanı zamanda hücrede oluşan mikro çatlakların oluşumuna da etki edecektir. Bu nedenle, güneş hücresindeki baraların sayının artırılmasının mikro çatlaklara olan etkisi de araştırmalıdır.

\section{KAYNAKLAR}

1. Braun, S., Hahn, G., Nissler, R., Pönisch, C., Habermann, D., 2013b. Multi-busbar Solar Cells and Modules: High Efficiencies and Low Silver Consumption. Energy Procedia 38, 334-339.

2. Braun, S., Hahn, G., Nissler, R., Pönisch, C., Habermann, D., 2013d. The Multi-busbar Design: An Overview. Energy Procedia 43, 86-92.

3. Braun, S., Micard, G., Hahn, G., 2012a. Solar Cell Improvement by using a Multi Busbar Design as Front Electrode. Energy Procedia 27, 227-233.

4. Braun, S., Nissler, R., Ebert, C., Habermann, D., Hahn, G., 2014. High Efficiency Multibusbar Solar Cells and Modules. IEEE Journal of Photovoltaics 4, 148-153.

5. Burschik, J., Shengzhao, Y., Bay, N., Crouse, K., De Rose, A., Hoffmann, A., Kühnlein, H., Lee, B., Letize, A., Passig, M., Pysch, D., Sieber, M., Verlinden, P., Vosteen, K., 2016. Transition to 4 and 5 BB Designs for $\mathrm{Ni} / \mathrm{Cu} / \mathrm{Ag}$ Plated Cells. Energy Procedia 98, 66-73.

6. Chen, N., Ebong, A., 2015. Investigating the Benefits of Multi Busbars for Industrial AlBSF Silicon Solar Cells, in: Photovoltaic Specialist Conference (PVSC), 2015 IEEE $42^{\text {nd }}$. IEEE, 1-5.

7. Ebong, A., Chen, N., Unsur, V., Chowdhury, A., Damiani, B., 2016. Innovative Front Grid Design, Four-Streets and Five-Busbars (4S-
5BB), for High Efficiency Industrial Al-BSF Silicon Solar Cell. IEEE Electron Device Letters 37, 459-462.

8. Lorenz, A., Senne, A., Rohde, J., Kroh, S., Wittenberg, M., Krüger, K., Clement, F., Biro, D., 2015. Evaluation of Flexographic Printing Technology for Multi-busbar Solar Cells. Energy Procedia 67, 126-137.

9. Rendler, L.C., Kraft, A., Ebert, C., Eitner, U., Wiese, S., 2016. Mechanical Stress in Solar Cells with Multi Busbar InterconnectionParameter Study by FEM Simulation, in: Thermal, Mechanical and Multi-Physics Simulation and Experiments in Microelectronics and Microsystems (EuroSimE), $2016 \quad 17^{\text {th }} \quad$ International Conference on. IEEE, 1-5.

10. Schinke, C., Kiefer, F., Offer, M., Hinken, D., Schmidt, A., Harder, N.P., Bock, R., Brendemuhl,T., Schmidt, J., Bothe, K., Brendel, R., 2012. Contacting Interdigitated Back-Contact Solar Cells with Four Busbars for Precise Current-Voltage Measurements under Standard Testing Conditions. IEEE Journal of Photovoltaics 2, 247-255.

11. Walter, J., Tranitz, M., Volk, M., Ebert, C., Eitner, U., 2014. Multi-wire Interconnection of Busbar-free Solar Cells. Energy Procedia 55, 380-388. 
